\title{
Tourism and Climate Change Mitigation, a Focus on Behavioral Change in Air Travel
}

\author{
Komukama Grace \\ Department of Forestry, Biodiversity and Tourism, \\ Makerere University, Kampala, Uganda
}

\begin{abstract}
It is undisputable that tourism has grown since the last decades and is the main source of foreign exchange for most developing countries. This growth is partially attributable to technological advancements in the aviation industry which has eased transportation from one region to another. However tourism contribution to carbon dioxide emissions through air transport is alarming with the sector contributing $\mathbf{4 0 \%}$ of the overall carbon print and therefore if immediate remedies are not undertaken the earth system may go in a state where it may never recover. The aim of the paper therefore is to point out how behavioral change is the immediate solution for reduction in climate change emissions especially those originating from the aviation industry, since reliance on the technological advancement is mythical. Content analysis was used to conduct the study by using the crucial keywords in three online databases and 17,966 results were analyzed. Findings indicate that behavioral change is the immediate remedy for climate change mitigation. This is coupled with the fact that most air customers are living in denial and yet governments and the aviation industry lack commitment to controlling climate change. Therefore, if any tangible reduction is to be achieved in climate change emanating from aviation industry, there is need for realistic measures from both the governments and the aviation sector in order to encourage individual behavioral changes.
\end{abstract}

Keywords:- Climate Change and Tourism, Air transport, Frequent flyers, Behavioral Change, Planetary Boundaries.

\section{INTRODUCTION}

For decades tourism industry has registered a tremendous growth and became one of the fastest growing sectors in the global world (Camillis, Raggi, \& Petti, 2010). Currently tourism is the major source of foreign exchange for most developing countries (Smedescu \& Fîntîneru,2013). According to UNWTO (2016) international tourism accounted for US\$ 1.5 trillion of export earnings in 2015 and was projected to grow from $3.5 \%$ to $4.5 \%$ in 2016 , the organization further forecasts that international tourism will reach 1.8 billion by 2030 . Research by Pincavage \& Fredericks (1987) shows that tourism growth has been made possible since the $1980 \mathrm{~s}$ with the introduction of fast airlines in that travel from one place to another became easy and less tedious.
Much as the transportation has accelerated tourism growth on the global scale it is associated with climate change challenges of global warming (Becken, 2007,Gossling \& Peeters, 2015) in that if immediate remedies are not done then the earth system may go in a state where it may never recover (Latour, 2014). Tourism's contribution to $\mathrm{CO} 2$ emissions through air transport are alarming with the sector contributing $40 \%$ of overall carbon print (Scott, Gössling, et al., 2016). Hall, et al.,(2015) predicted that GHG emissions from tourism are going to double due to increased long haul travels and changing life styles and therefore there is need to find practical measures of reducing the carbon emissions especially from aviation industry before the earth moves beyond the tipping point.

The use of fossil fuels in the aviation industry has been pointed out as the biggest contributor of carbon emissions that deteriorate further climate change phenomenon (Scott, Hall, \& Gössling, 2015) yet the aviation sector is in denial and doesn't have any tangible strategies of reducing emissions(Nelson, 2016) though some airlines have engaged in afforestation like the Costa Rican Nature Air but this does not reduce emissions much as it is a good move (Gossling, 2010). Climate change needs to be handled as a critical issue since it causes lasting effects which are irreversible such as famines which eventually lead to wars especially in Africa (Scheffran \& Battaglini, 2011), loss of species (Hall, 2010) and eventual extinction of human race (Latour, 2014)

\section{PURPOSE OF THE REVIEW}

Since climate change and tourism are closely related with the later contributing $40 \%$ through aviation there is an argent need for airline customers to change their consumption behaviors (Hall et al., 2015). Moreover it is a small percentage of global citizens that use the air transport yet it affects billions of people (Gossling \& Nilsson, 2010) for instance more than half population of Africans and Asians have never travelled by air yet are affected by climate change through long periods of droughts (Scheffran \& Battaglini,2011). Research by Goodrich (2002) shows that after the September $11^{\text {th }}$ in the USA there was a noticeable positive improvement in the emissions since demand for air travel in the USA declined, so as rightly argued by Rockström et.al., (2014) that if the carbon emissions from transport and other critical thresholds in the planetary boundaries reduced then the earth system 
wouldn't go beyond the tipping point and will probably be safe for another 1000 years.

The most critical thresholds in the planetary boundaries to some extent have received practical solutions for instance minimal water use by hotels e.g. Hilton hotel (Gossling, 2010) afforestation in many parts of the world (Chazdon, 2008), biodiversity conservation improvement through protected areas (Pfueller, Lee, \&Laing,2011) but yet no reliable mitigation measures in aviation industry have been enforced by ICAO (Scott, Hall, \& Gössling, 2016).Other transportation sectors have implemented safe measures for instance the use of bio fuels in cars (Ryan, Convery, \& Ferreira, 2006), adaptation of slow travel in most European cities (Markwell, Fullagar, \& Wilson, 2012) and the growing trend of walkability (Ewing \& Handy, 2009 , Lee $\&$ Talen, 2014) all of which are generous to the environment and climate at large. Deliberations proposed by the Paris Agreement are unlikely to be achieved if drastic changes in aviation industry are not undertaken (Scott, Gössling, et al., 2016). Air travel is still problematic and the proposed use of bio fuels as an alternative fuel is unlikely to be successful because of its associated limitations (Gegg, Budd, \& Ison, 2014)and as Chapman (2007) proposed that change in customer behaviors is the immediate possible measure that can reduce the carbon emissions particularly the emissions associated with airline travel. Furthermore other scholars such as Akerman \& Hojer, (2006),Gössling et al.,(2007) and (Hall, 2011) suggested different actions such as change in government policies, advanced technological change and behavioral change as possible solution measures for climate change phenomenon from aviation sector. In this particular literature review the researcher aim was to analyze behavioral change in order to find out whether it can bring about the sought reduction in carbon emissions.

\section{METHODOLOGY}

In undertaking the project the researcher used desk research approach to collect related literature in connection to the topic of study. This approach was chosen because of the need to find other scholars findings related to the topic (Kombo \& Tromp, 2006). The researcher used three databases i.e. Web of Science, EBSCO, Google Scholar and these were chosen because they were relevant to the topic with most peer reviewed articles in humanities. In all databases the researcher used the key words of climate change and tourism in the first search as a helicopter perspective in order to get a real picture of the topic. In Google scholar 724,000 results were got, 816 in EBSCO and 958 in Web of Science. Then in search two climate change and tourism, planetary boundaries, behavioral change and air transport keywords were used and got 1,990,000 results in Google scholar, 899 in Web of Science and 647 in EBSCO and the researcher interchanged key words and got 15900 in Google Scholar, 51 in Web of Science and 55 in EBSCO. Since the researcher was now sure that both old and new articles were included in the above searches the researcher limited the last search to the last fifteen years and combined three keywords i.e. climate change and tourism and air transport and got 17966 from the three databases.After this crucial stage the researcher choose articles by reading the title and abstracts of selected journals to make judgments on whether to include or exclude the article from literature review. Thechosen articles fulfilled the following criteria i.e. peer reviewed articles, English articles and the articles and reports which focused on climate change and aviation industry while the ones which were excluded were articles from conferences, dissertations, non peer reviewed articles and articles on climate change and tourism sustainability in destinations.

To exhaust the search the researcher also retrieved the articles in the reference pages of chosen articles until saturation point since according to Randolph, (2009), pg 9

....electronic searches lead to only ten percent of the articles that will comprise an exhaustive review and there are several approaches to locate the remaining review but the most effective method may be to search the references of the articles that were retrieved....

Then after identifying therelevant articles the researcher begun on data evaluation. The researcher read all the articles pressing more emphasis on research outcomes and also tried to identify gaps in the literature. It was from these findings that the researcher indentified three themes (i.e. Awareness, government intervention and technological myths) and was able to make syntheses, evaluations and discussions.

\section{REVIEW RESULTS}

\section{A. Awareness}

The most common theories for explaining pro environmental behaviors are Schwartz theory of norm activation and Stern's theory of value belief norm. In the former theory it proposes that that people are willing to change behaviors especially when they have knowledge and awareness that their behaviors pose threats to others and yet they have options to reduce such happenings (Schwartz,1977). This theory was upgraded by Stern (2000) who claimed that knowledge is not the most important factor in changing behaviors but personal values precede environmental factors especially if individuals perceive that their values will be threatened then they have a strong force to act in order to avoid those negative happenings.

Earlier argument by Burgess, Harrison, \& Filius (1998) of pro environmental behavior suggested that if people have knowledge about the environment then their concern would increase hence influencing behavioral change a notion that was criticized by Kollmus \& Agyeman (2002) who claimed that there is a very big gap between knowledge and behavioral change and this was later confirmed by Becken (2007) research which confirmed that there is a weak relationship between climate change knowledge influencing change of behavior. 
Research by Patt \& Dessai (2005) shows uncertainty exists in the minds of people concerning climate change in that they perceive that it is an issue exaggerated by scientists and the situation is even made worse by the media who most of the times are not positive in climate change phenomenon. And yet tourists perceptions and behavior are heavily influenced by media in that any reliable information by media maybe taken wholly as truth (Gossling et.al., 2012).The situation is further deteriorated by the green wash fatigue whereby people give up their conservation habits claiming that their personal contribution cannot do much because anyway the majority of people are practicing unsustainable practices (Mckercher, Prideaux, Cheung, \& Law, 2010).

The public perceive that airlines already have measures of climate change and therefore they do not need to input their individual effort towards the same cause whereby a good scenario is usually portrayed by airlines in that they are defensive and don't communicate to customers what is really happening and at times give false information that they are using bio fuels which is not the case in other wards they use a lot of green washing (Wymer, 2010,Burns \& Cowlishaw, 2014)

Tourism behavioral change may be difficult because of the consumer's belief that it is their right to travel even to the extent that even environmentally sensitive tourists may not be willing to alter their travel pattern (Gossling et al., 2013). The benefit delivered from travelling in the plane such as its swiftness has led to the majority of people not willing to give up airline travel even for shorter distances despite climate change issues associated with it (Mckercher,et.al.,2010). Cultural aspects in terms of travel behavior especially in European countries is another setback in that travel culture is embedded in children at a young age and therefore difficult to change at an adult age (Eden, 1993,Gössling \& Cohen, 2014). Recent research shows that eco labels don't even influence customer behaviors at all (Gossling \& Buckley,2016). Kroesen (2013) research further found out that there is no relationship between environmental awareness and behavioral change but denial of personal contribution and apportioning blame on others was the limiting attribute to behavioral change.

Annabel et al., (2006) research revealed that the UK residents recognized climate change concept but only a third of the population agreed that air transport was the main cause of climate change and this to some extent explains air transport continued growth among UK residents for the last decades. This perspective was in alignment with Gössling, Bredberg, Randow, Sandstrom, \& Svensson (2006) and Shaw \& Thomas, (2006) researches where the respondents acknowledged climate change problem and attributed it to other aspects such as waste and land development but not to their travel behaviors, only a small portion of $17 \%$ of holidaying tourists in Zanzibar in Gössling et al.,(2006) research attributed climate change to green house gases emanating from air transport while in Shaw \& Thomas (2006) a few respondents who acknowledged the contributions of climate change were not willing to change their behaviors claiming that individual behavioral change could not combat the huge problem of climate change. Becken (2007) and Cohen et al.(2011) also found out that tourists felt that climate change mitigation was not their personal responsibility but for governments. More to that Gössling, Haglund, Kallgren, Revahl, \& Hultman (2009) found out that many Swedish citizens acknowledged their individual contribution to climate change though they placed much blame to aviation industry, government and intergovernmental organizations.

Böhler, Grischkat, Haustein, \& Hunecke (2006, p.667) noted that much as tourists are aware of their contribution to climate change problem they tend to live in denial; "the motivation for the long haul traveler to get into contact with foreign cultures, to explore foreign landscapes or to exhibit a lifestyle different from the mainstream population might be stronger than the realization that air travel causes environmental damage". This was later confirmed by Becken (2007) findings which showed that tourists considered flying as their freedom and therefore were not willing to give it up all in the name of climate change but were willing to practice good environmental behaviors at the home of residence.

Steg, Perlaviciute, \& Van der Werff (2014) point out, that values are very important in the study of pro environmental behaviours since they are culturally shared and therefore different individuals react differently in face of value conflicts. Many cultures perceive air travel differently and therefore attach values to flying differently. Randles \& Mander (2009) found out in their research that air transport was taken as a form of a higher social status in the community in that reduction of flying in such a community would be seen as a lower standard or quality of living.Values can therefore cause conflict towards environmental attitudes and this results at times shifting the blame to others or living in denial as shown by Becken (2007) as tourists may end up shifting the blame on governments, aviation industry and international organizations (Cohen, Higham, \& Cavaliere, 2011).

Studies by Cohen \& Higham (2011) showed that people were not willing to change their travel behaviors despite their climate knowledge because they attached a lot of importance to holidays than climate change phenomenon, similar study by Mckercher et al., (2010) in Hong Kong also revealed that the frequent tourists had climate change knowledge but were unwilling to change their travel behaviors.

Moreover research by Randles \& Mander (2009b) revealed that travelers were against restriction measures for travel limitation but were less defiant to high taxes on their tickets so long as the money raised was used to mitigate climate change emanating from air transport. Similar findings were found by Barr, Shaw, Coles, \& Prillwitz (2010) where travelers were not against high taxes on air transport but resistant concerning any resistive measures on their air travels. All these findings agree with Lorenzoni, 
Nicholson-Cole, \& Whitmarsh (2007, p.446) in which he stated that, "it is not enough for people to know about climate change in order to be engaged ; they also need to care about it, be motivated and be able to take action".

\section{B. Government Intervention}

Although government policies can mitigate carbon emissions their effectiveness is slow (Chapman, 2007b). Governments and tourism industry have not placed a lot of emphasis on devising ways of mitigating climate change phenomenon in that they seem to be reluctant with continued failure to bring about the emissions trading schemes by periodically extending deadlines (J. Higham, Cohen, Peeters, et al., 2016). Though government tend to rest on the assurance that a solution will be got through technology solutions it is evident that the proposed measures such as use of bio fuels may not bring about the desired solutions due to its limitations (Gossling, Hall, Peeters \& Scott, 2010). Becken (2007) research showed that many respondents blamed the governments for not doing enough in terms of climate mitigation such as regulation policies, enforcement and information assimilation.

Government encouragement of voluntary behavioral change has not been successful and yet lack commitment to implement policies that mitigate climate change in air transport (J. Higham, Cohen, Cavaliere, \& Reis, 2016).Much as behavioral change using social marketing is seen as an alternative strategy (Hall, 2013) yet it not sustainable as individuals usually go back to their old habits after the steering factors reduce (Peattie \& Peattie, 2009) but as Wymer (2010) argues it is better to start with regulating policies and then educate masses through social marketing because such measures are sustainable.

Research by Thaler \& Sunstein (2008) shows that government are reluctant to enforce climate change mitigation policies instead use behavioral economics as a way to enforce changes in people's behaviors. As was pointed out by Graham, Camerer, \& Loewenstein (2005) behavior economics is the best way to change people's psyche without them feeling that their freedoms are being encroached on.

Becken (2007) research showed that global air tax is a realistic measure for carbon emissions mitigation and his research was later supported by Gossling et al., (2013) findings which showed that compulsory government policies can easily bring about behavioral change however Gössling \& Cohen (2014) points out that without addressing the transport taboos then it is close to impossible for carbon emissions to be reduced. Recent research by Higham et al., (2016) shows that much as behavioral change can be an immediate measure to reduce carbon emissions yet it can't be effective in isolation in that there is need for a radical change in public provisions to easy or encourage behavior change a situation according to Dillimono \& Dickinson (2015) that is a nightmare especially in developing countries whereby the public infrastructures are in a very bad shape hence limiting behavioral change.

\section{Technological myths}

Aviation dedication to climate change mitigation is questionable in that the industry encourage customers to frequently travel in order to earn mileage points yet hyper mobility should not be encouraged (Young, Higham, \& Reis, 2014).However airlines have persistently informed customers that emissions will decline up to zero in future when the sector begins to use bio fuels yet there is a limited possibility of technological potential to reduce carbon emissions in air transport in other wards most of the proposed solutions are myths and unrealistic (Peeters, Higham, Kutzner, Cohen, \& Gössling, 2016) as Borup, Brown, \& Konrad (2006) puts it that some statements in aviation industry are based on technological advancement expectations which at times are misleading and practically may not yield an tangible results since Nygren, Aleklett, \& Hook (2009) research shows that adjusting to other sources of fuel such as biogas maybe unsustainable because of the limitations associated with production.

Several studies have showed that people are not changing their travel despite their knowledge about climate change and continue to take trips without any hesitance (Cohen et al., 2011) the situation is even made worse with flyers miles given by different airlines to maintain the customer base (Young et al., 2014). As if that is not enough there is growth of tourism from emerging regions will further deteriorate climate since most of the trips from emerging regions are long haul yet their contribution is neglected as noted in the Freiberg conference that"it should be noted in conclusion that the focus is western centric. These lines of inquiry need to be extended to emergent world regions where rapidly expanding middle classes are fueling increases in aero consumption"(Higham et al., 2013,p.962). There is need for global mitigation for climate change especially from aviation industry since it contributes the highest carbon emissions and therefore there is need for cooperation for all countries of the world. There is a wrong perception that that there aren't many travelers from developing countries yet this is not true because the middle class people from these countries especially the academics and business people take several long haul trips in a year (Heinz \& O Connell, 2013). The dominant airlines in these regions for instance emirates airways operates five days a week carrying traffic every day from developing countries (Hussain, Nasser, \& Hussain, 2015), given the profit making perspectives of airlines they would have reduced routes to these countries and therefore this shows that these regions are contributing to air emissions though they have not attracted the attention of researchers as noted at the Freiburg conference. Different climate change scholars (Chapman, 2007; Gossling \& Peeters, 2007; Hall, 2011) have analyzed this phenomenon and have come to a conclusion that the immediate solution to carbon emissions from the air sector is behavioral change since the industry and governments are playing a low profile due to capitalism. Moreover this behavioral change doesn't need to be practiced by only 
travelers from developed countries but by all global travelers including those from developing countries if noticeable carbon emissions reduction is to be realized.

\section{DISCUSSION}

Most scholars in this review used one type of research methodology either qualitative or quantitative and yet this strategy may lead to some vital information being left out since it is usually better to use a combination of two methodologies to get a realistic general picture (Hussein, 2009). More to that most of the articles are written in developed countries and there is little focus on developing countries yet if carbon emission reduction is to be achieved climate change issues need to be analyzed globally.

Much as Burgess et al., (1998) research showed that people's behaviors do not change due to lack of climate change knowledge this was refuted by many scholars e.g. Kollmus \& Agyeman, (2002), Becken, (2007), Patt \& Dessai, (2005),Mckercher et al., (2010) and Burns \& Cowlishaw, (2014) who argue that people have knowledge about climate change but unwilling to change their behaviors due to various reasons such as denial of climate change phenomenon (Patt \& Dessai, 2005), unseriousness of climate change issues by the media (Stefan Gössling \& Cohen, 2014), misleading information from aviation industry(Burns \& Cowlishaw, 2014),freedom mentality in customers psyches (Gossling et al., 2013), reliable and timely transport of airlines (Mckercher et al., 2010),cultural aspects (Eden, 1993, Gössling \& Cohen, 2014). As Kroesen, (2013) research shows there is no relationship between environmental awareness and behavioral change but denial of personal contribution and apportioning blame on others was the limiting attribute to behavioral change.

If climate change mitigation is to take place there is need for government intervention (Chapman, 2007).Much as governments realize their role in mitigating climate change they are reluctant and keep on extending deadlines for example in the issue of carbon trading schemes (Higham, Cohen, Cavaliere, et al., 2016) and also limited by their political ambitions whereby political parties that promise reduction of carbon emissions usually face voter reduction and not usually re-elected in office for example in Higham, Cohen, Cavaliere, et al.,(2016) pg.9 research, one respondent said, "I remember when the green party was running for the first time in the election phase before that they had this climate expert and she was saying publically that people should only take a long haul trip every three or four years, there was a public outcry and they lost several percentage points of their potential voters because of that."Governments also have false hope that technological innovation will solve the climate change phenomenon however research by Gossling et al., (2010) shows that proposed measures such as use of bio fuels may not bring about the desired solutions due it's limitations in production.
Recent research by Higham, Cohen, Peeters, et al., (2016) shows that government's encouragement of voluntary behavioral change has not been successful and therefore there is need for governments to formulate policies to mitigate climate change. Hall, (2013) research shows that social marketing can be an effective tool to nudge people to change their behaviors however Peattie \& Peattie, (2009) research had earlier showed that social marketing is effective for a short period of time as individuals usually go back to their old habits especially after the steering period.

One way in which airlines can influence customers to engage in green strategy is through voluntary carbon off setting where each passenger is held accountable for his/her carbon emissions however this strategy is still low and lacks support from mass media (Kim, Yun, Lee, \& Ko, 2016).Voluntary off setting will not offset carbon emissions alone there is need of some strict measures or policies from government to mitigate climate change (Mckercher et al., 2010)

The most practical way of achieving behavioral change as shown by Thaler \& Sunstein, (2008) research is the use of behavioral economics where people's psyches are changed without them feeling that their freedoms are being encroached on and this was supported by Gossling et al., (2013) research which showed that compulsory government policies can easily bring about behavioral change but recent research by Higham et al., (2016) and Dillimono \& Dickinson, (2015) research shows that much as government policies can do much to encourage behavioral change they need to play their part in providing good public infrastructures to easy the process of changing behaviors.

In this literature review a big limiting factor was discovered and that is technological myths in that the aviation industry has overtime given false hope to its customers that the situation is under control (Peeters et al., 2016) and have continuously encouraged people to fly more hence a flyers dilemma for airline customers (Young et al., 2014) so the customers are left divided and not knowing what exactly need to be done and this is even made worse by the media who are anti-environmental and tend to argue that the issue of climate change is exaggerated by scientists ( Gossling et al., 2012).

Unrealistic and false targets by the aviation industry have negatively influenced the public and policy makers to wholly believe that carbon emissions from transport are under control yet it is just brain washing played by airline actors(Stefan Gössling \& Cohen, 2014). 


\section{CONCLUSION}

In conclusion therefore people have knowledge about climate change problems but are unwilling to change their behaviors voluntarily and the situation is even made worse by aviation industry who do not communicate the right information to their customers but tend to camouflage the information by giving false hope to the public, if the issue of climate change is to be solved there is need for government intervention in terms of enforcing policies and also provision of reliable public infrastructures to ease the process of behavioral change.

\section{REFERENCES}

[1]. Akerman, J., \& Hojer, M. (2006). How much transport can the Climate stand?Sweden on a Sustainable path in 2050. Energy Policy, 34, 19441957.

[2]. Annabel, J., Lane, B., \& Kelay, T. (2006). An evidence based review of public attitudes to climate change and transport behaviour.

[3]. Barr, S., Shaw, G., Coles, T., \& Prillwitz, J. (2010). "A holiday is a holiday": Practicing sustainability, home and away. Journal of Transport Geography, 18, 474-481.

[4]. Becken, S. (2007). Tourists ' Perception of International Air Travel' s Impact on the Global Climate. Journal of Sustainable Tourism, 15(4). http://doi.org/10.2167/jost710.0

[5]. Böhler, S., Grischkat, S., Haustein, S., \& Hunecke, M. (2006). Encouraging environmentally sustainable holiday travel. Transportation Research Part A,40, 652-670.

[6]. Borup, M., Brown, N., \& Konrad, K. (2006). The Sociology of expectations in science and technology. Technology Analysis and Strategic Management, 18(13/14), 285-298.

[7]. Burgess, J., Harrison, C., \& Filius, P. (1998). Environmental Communication and the Cultural politics of Environmental citizenship. Environmental Planning A, 30(8), 1445-1460.

[8]. Burns, P. M., \& Cowlishaw, C. (2014). Climate change discourses: how UK airlines communicate their case to the public. Journal of Sustainable Tourism, 22(5), 750-767.

[9]. Camillis, C, D., Raggi, A., \& Petti, L. (2010). Tourism LCA: State -of-the art and perspectives. International Journal of Life Cycle Assessment, 15(2), 148-155.

[10]. Chapman, L. (2007a). Transport and climate change: a review. Journal of Transport Geography, 15, 354 367. http://doi.org/10.1016/j.jtrangeo.2006.11.008

[11]. Chapman, L. (2007b). Transport and climate change: a review. Journal of Transport Geography, 15(5), 354-367. http://doi.org/10.1016/j.jtrangeo.2006.11.008

[12]. Chazdon, R. . (2008). Beyond Deforestation:Restoring forests and ecosystem in degraded lands. Science, 320(5882), 1458-1460.
[13]. Cohen, S. ., \& Higham, J. E. . (2011). Eyes wide shut?UK consumer perceptions on aviation climate impacts and travel decisions to New Zealand. Current Issues in Tourism, 14(4), 323-335.

[14]. Cohen, S. ., Higham, J. E. ., \& Cavaliere, C. . (2011). Binge flying behavioural addiction and climate change. Annals of Tourism Research, 38(310701089).

[15]. Dillimono,H, D., \& Dickinson,J, E. (2015). Travel,tourism,climate change and behavioral change: travelers perspectives from a developing country,Nigeria. Journal of Sustainable Tourism, 23(3), 437-454.

[16]. Eden, s. (1993). Individual environmental responsibility and it,s role in public environmentalism. Environment and Planning A, 25, 1743-1743.

[17]. Ewing, R., \& Handy, S. (2009). Measuring the Unmeasurable: Urban Design Qualities Related to Walkability. Journal of Urban Design, 14(1), 65-84. http://doi.org/10.1080/13574800802451155

[18]. Gegg, P., Budd, L., \& Ison, S. (2014). The market development of aviation biofuel:Drivers and constraints. Journal of Air Transport Management, $39,43-40$.

[19]. Goodrich, 2002. (2002). September 11,2001 attack on America.A record of immediate impacts and reactions in the USA travel and tourism industry. Tourism Management, 23(6), 573-580.

[20]. Gossling, S. (2010). Carbon Management in Tourism. Routledge, Taylor and Francis group.

[21]. Gössling, S., Bredberg, M., Randow, A., Sandstrom, E., \& Svensson, P. (2006). Tourist perceptions of climate change: A study of international tourists in Zanzibar. Current Issues in Tourism, 9(4), 419-435.

[22]. Gössling, S., Broderick, J., Upham, P., Ceron, J.-P., Dubois, G., Peeters, P., \& Strasdas, W. (2007). Voluntary Carbon Offsetting Schemes for Aviation: Efficiency, Credibility and Sustainable Tourism. Journal of Sustainable Tourism, 15(3), 223-248. http://doi.org/10.2167/jost758.0

[23]. Gossling, S., \& Buckley, R. (2016). Carbon labels in tourism: persuasive communication? Journal of Cleaner Production, 111, 358-369. http://doi.org/10.1016/j.jclepro.2014.08.067

[24]. Gössling, S., \& Cohen, S. (2014). Why sustainable transport policies will fail: EU climate policy in the light of transport taboos. Journal of Transport Geography, 39, 197-207. http://doi.org/10.1016/j.jtrangeo.2014.07.010

[25]. Gössling, S., Haglund, L., Kallgren, H., Revahl, M., \& Hultman, J. (2009). Swedish air travelers and voluntary carbon offsets: Towards the co-creation of environmental value? Current Issues in Tourism, 12(1), 1-19.

[26]. Gossling, S., Hall, C. ., Peeters, P., \& Scott, D. (2010). The future of tourism.Can tourism growth and climate policy be reconciled? Tourism Recreation Research, 35(2), 119-130. 
[27]. Gossling, S., \& Nilsson,J, H. (2010). Frequent Flyer programmes and reproduction of mobility. Environment and Planning, 42(241-52).

[28]. Gossling, S., \& Peeters, P. (2007). "It does not harm the environment"An analysis of industry discourses on tourism,air travel and the environment. Journal of Sustainable Tourism, 15(402-417).

[29]. Gossling, S., \& Peeters, P. (2015). Assessing tourism's global environmental impact 1900-2050. Journal of Sustainable Tourism, 23(5), 639-659. http://doi.org/10.1080/09669582.2015.1008500

[30]. Gossling, S., Scott, D., Hall, C. ., Ceron, J., \& Dubois, G. (2012). CONSUMER BEHAVIOUR AND DEMAND RESPONSE OF TOURISTS. Annals of Tourism Research, 39(1), 36-58. http://doi.org/10.1016/j.annals.2011.11.002

[31]. Gossling, S., Scott, D., \& Hall, C. M. (2013). Challenges of tourism in a low-carbon economy. WIRES Clim Change, 4, 525-538. http://doi.org/10.1002/wcc. 243

[32]. Graham, J., Camerer, F., \& Loewenstein, G. (2005). Adam Smith,Behaviour Economist. The Journal of Economic Perspectives, 19(3), 131-145.

[33]. Hall, C, M. (2010). Tourism and biodiversity:more significant than climate change? Journal of Heritage Tourism, 5(4), 253-266.

[34]. Hall, C, M., Amelung, B., Cohen, S., Eligelaar, E., Gossling, S., Higham, J., ... Scott, D. (2015). On climate change skepticism and denial in tourism. Journal of Sustainable Tourism, 23(1), 4-25.

[35]. Hall, C. . (2013). Framing behavioural approaches to understanding and governing sustainable tourism consumption: beyond neoliberalism, "nudging" and "green growth". Journal of Sustainable Tourism, 21(7), 1091-1109.

[36]. Hall, C. M. (2011). Policy Learning and policy failure in sustainable tourism governance:from first and second order to third order change? Journal of Sustainable Tourism, 19(4-5), 649-671.

[37]. Heinz.S, \& O Connell. (2013). Air transport in Africa: toward sustainable business models for African airlines. Journal of Transport Geography, 31, $72-83$.

[38]. Higham, J., Cohen, S. A., Cavaliere, C. T., \& Reis, A. (2016). Climate change, tourist air travel and radical emissions reduction. Journal of Cleaner Production, 111 , 336-347. http://doi.org/10.1016/j.jclepro.2014.10.100

[39]. Higham, J., Cohen, S. A., Peeters, P., Gössling, S., Higham, J., Cohen, S. A., ... Gössling, S. (2016). Psychological and behavioural approaches to understanding and governing sustainable mobility. Journal of Sustainable Tourism, 9582(December). http://doi.org/10.1080/09669582.2013.828733

[40]. Higham, J. E. ., Cohen, S. ., Peeters, P., \& Gossling, S. (2013). Psychological and behavioural approaches to understanding and governing sustainable mobility. Journal of Sustainable Tourism, 21(7), 949-967.
[41]. Hussain, R., Nasser, A. ., \& Hussain, Y. . (2015). Service quality and customer satisfaction of a UAE based airline:An empirical investigation. Journal of Air Transport Management, 167-175.

[42]. Hussein, A. (2009). The use of triangulation in social sciences research:Can qualitative and quantitative methods be combined. Journal of Comparative Social Work, 41.

[43]. Kim, Y., Yun, S., Lee, J., \& Ko, E. (2016). How consumer knowledge shapes green consumption : an empirical study on voluntary carbon offsetting. International Journal of Advertising, 487(December).

[44]. Kollmus, A., \& Agyeman, J. (2002). Mind the gap:Why do people act environmentally and what are the barriers to pro-environmental behaviour? Environ Ed. Res, 8, 239-260.

[45]. Kombo, D. ., \& Tromp, D. L. . (2006). Proposal and Thesis Writing. Paulines Publications,Africa. Retrieved from www.paulinesafrica.org

[46]. Kroesen, M. (2013). Exploring people's viewpoints on air travel and climate change: Journal of Sustainable Tourism, 21(2), 271-290.

[47]. Latour, B. (2014). The climate to come depends on the present time, 1-4. Retrieved from http://www.bruno-

latour.fr/sites/default/files/downloads/14-11ANTHROPO-transl-GB.pdf

[48]. Lee, S., \& Talen, E. (2014). Measuring walkability:Anote on auditing methods. Journal of Urban Design, 19(3), 368-388.

[49]. Lorenzoni, I., Nicholson-Cole, S., \& Whitmarsh, L. (2007). Barriers perceived to engaging with climate change among the UK public and their policy implications. Global Environmental Change, 17, 445-459.

[50]. Markwell, K., Fullagar, S., \& Wilson, E. (2012). Reflecting upon slow travel and tourism experiences. In Slow tourism:experiences and mobilities (pp. 227233).

[51]. Mckercher, B., Prideaux, B., Cheung, C., \& Law, R. (2010). Achieving voluntary reductions in the carbon footprint of tourism. Journal of Sustainable Tourism, $18(3)$, 297-317. http://doi.org/10.1080/09669580903395022

[52]. Nelson, A. (2016). European diplomats criticize UN plan to curb airline emissions. Retrieved from www.theguardian.com

[53]. Nygren, E., Aleklett, K., \& Hook, M. (2009). Aviation fuel and future oil production scenarios. Energy Policy, 37(10), 4003-4010.

[54]. Patt, A., \& Dessai, S. (2005). Communicating Uncertainity:Lessons learned and suggestions for climate change assessment. Geoscience, 337, 425441.

[55]. Peattie, K., \& Peattie, S. (2009). Social marketing:a pathway to consumption reduction. Journal of Business Research, 62, 260-268. 
[56]. Peeters, P., Higham, J., Kutzner, D., Cohen, S., \& Gössling, S. (2016). Are technology myths stalling aviation climate policy? Transportation Research Part D: Transport and Environment, 44, 30-42. http://doi.org/10.1016/j.trd.2016.02.004

[57]. Pfueller, S., Lee, D., \& Laing, J. (2011). Tourism partnerships in protected areas:exploring contributions to sustainability. Environmental Management, 48(4), 734-749.

[58]. Pincavage, J., \& Fredericks, A. (1987). 1988 Outlook for air travel and related business. In Proceedings of the US travel data center,s thirteen annual travel outlook forum (pp. 107-124). Reno,Nevada.

[59]. Randles, S., \& Mander, S. (2009a). Aviation,consumption and the climate change debate: "Are you going to tell me off for flying?" Technology Analysis and Strategic Management, 21(193-113).

[60]. Randles, S., \& Mander, S. (2009b). Practice(s) and ratchet(s):A sociological examination of frequent flying. In Climate Change and Aviation:Issues, Challenges and Solutions (pp. 245271). London: Earth Scan Limited.

[61]. Randolph, J. . (2009). A guide to writing the dissertation literature review. Practical Assessment Research and Evaluation, 14(13).

[62]. Rockström, J., Steffen.W.L, Noone, K., Persson, A., \& Chapin, F. . (2014). Planetary Boundaries: Exploring the safe operating space for humanity. Ecology and Society, 14(2), 81-87. http://doi.org/10.1007/s13398-014-0173-7.2

[63]. Ryan, L., Convery, F., \& Ferreira, S. (2006). Stimulating the use of biofuels in the European Union:Implications for climate change policy. Climate Change Policy, 34(17), 3184-3194.

[64]. Scheffran, J., \& Battaglini, A. (2011). Climate and conflicts:the Security risks of Global Warming. Regional Environmental Change, 11, 27-39.

[65]. Schwartz,S, H. (1977). Normative influences on altruism. Advances in Experimental Social Psychology, 10, 221-279.

[66]. Scott, D., Gössling, S., Hall, C. M., Peeters, P., Scott, D., Gössling, S., ... Peeters, P. (2016). Can tourism be part of the decarbonized global economy? The costs and risks of alternate carbon reduction policy pathways. Journal of Sustainable Tourism, 21(1), 5272. http://doi.org/10.1080/09669582.2015.1107080

[67]. Scott, D., Hall, C. M., \& Gössling, S. (2015). A review of the IPCC Fifth Assessment and implications for tourism sector climate resilience and decarbonization. Journal of Sustainable Tourism, 9582(August), $1-23$. http://doi.org/10.1080/09669582.2015.1062021

[68]. Scott, D., Hall, C. M., \& Gössling, S. (2016). A report on the Paris Climate Change Agreement and its implications for tourism: why we will always have Paris. Journal of Sustainable Tourism, 9582(October), 1-16. http://doi.org/10.1080/09669582.2016.1187623.
[69]. Shaw, S., \& Thomas, C. (2006). Discussion note:Social and cultural dimensions of air travel demand:Hyper -mobility in the UK? Journal of Sustainable Tourism, 14(2), 209-215.

[70]. Smedescu, D., \& Fîntîneru, G. (2013). Tourism phenomeon in the post crisis economy. Scientific Papers Series - Management, Economic Engineering in Agriculture and Rural Development, 13(2), 393396.

[71]. Steg, L., Perlaviciute, G., \& Van der Werff, E. (2014). The significance of hedonic values of environmental relevant attitudes, preferences and actions. Environment and Behaviour, 46(2), 163-192.

[72]. Stern,P, C. (2000). Toward a coherent theory of environmentally significant behaviour. Journal of Social Issues, 56, 407-424.

[73]. Thaler, R. ., \& Sunstein, C. . (2008). Improving decisions about health,wealth and happiness. Constitutional Political Economy, 19(4), 356-360.

[74]. UNWTO. (2016). International tourism continues to grow above average in the first four months of 2016. Retrieved from www.media.unwto.org

[75]. Wymer, T. (2010). Rethinking the boundaries of social marketing :activism or advertising? Journal of Business Research, 63(2), 99-103.

[76]. Young, M., Higham, J. E. S., \& Reis, A. C. (2014). “ Up in the air ": A conceptual critique of flying addiction. Annals of Tourism Research, 49, 51-64. http://doi.org/10.1016/j.annals.2014.08.003 